\section{TOTAL SYNTHESIS OF STREPTOMYCIN}

Sir :

Streptomycin discovered by WAKSMAN and coworkers $^{1)}$ in 1944 was the first useful Streptomyces antibiotic. Its structure was established ${ }^{2)}$ by 1948 except for the glycosidic linkage between streptose and streptidine which was again shown ${ }^{3,4)}$ to be $\alpha$ - $\mathrm{L}$. However, the total synthesis of the molecule has not been achieved. $\mathrm{We}^{5)}$ have recently prepared by total synthesis dihydrostreptomycin (DSM) which is produced by hydrogenation ${ }^{8,7)}$ of streptomycin or by direct fermentation. ${ }^{8)}$ In this paper, we wish to report the conversion of DSM to streptomycin, thereby completing the first rational synthesis of streptomycin.

When DSM (1) trihydrochloride was treated with equimolecular quantities of benzyl chloroformate and sodium carbonate in aqueous acetone with cooling, benzyloxycarbonylation selectively occurred at the N-methyl group of the L-glucosamine portion, giving $2^{\prime \prime}-\mathrm{N}$ benzyloxycarbonyldihydrostreptomycin (2) dihydrochloride $(77 \%):[\alpha]_{\mathrm{D}}^{00}-71^{\circ}\left(c 1.5, \mathrm{H}_{2} \mathrm{O}\right)$; NMR (in $\left.\mathrm{D}_{2} \mathrm{O}\right): \delta 3.10\left(3 \mathrm{H} \mathrm{s}, \mathrm{NCH}_{3}\right), 7.57$ $\left(5 \mathrm{H} \mathrm{s}, \mathrm{C}_{6} \mathrm{H}_{5}\right.$ ). Calcd. for $\mathrm{C}_{29} \mathrm{H}_{47} \mathrm{~N}_{7} \mathrm{O}_{14} \cdot 2 \mathrm{HCl}$. $\mathrm{H}_{2} \mathrm{O}: \quad \mathrm{C} 43.07, \mathrm{H}$ 6.36, N 12.12, $\mathrm{Cl} 8.77$. Found: C 43.20, H 6.20, N 11.93, Cl 8.79.

Treatment of 2 with excess 2,2-dimethoxypropane in the presence of a trace amount of $p$-toluenesulfonic acid gave a mixture of perO-isopropylidenated products. However, on treatment with $20 \%$ acetic acid in methanol at $50^{\circ} \mathrm{C}$ for 4.5 hours, the mono-isopropylidene derivative (3) was obtained; $49 \% ;[\alpha]_{\mathrm{D}}^{30}-73^{\circ}$ $(c), \mathrm{H}_{2} \mathrm{O}$ ); NMR (in $\mathrm{D}_{2} \mathrm{O}$ ) $: \delta 1.25(3 \mathrm{H} \mathrm{d}$, $\mathrm{CCH}_{3}$ ), 1.27 and 1.37 (each $3 \mathrm{H} \mathrm{s}$, isopropylidene), $3.08\left(3 \mathrm{H} \mathrm{s}, \mathrm{NCH}_{3}\right), 7.55\left(5 \mathrm{H} \mathrm{s}, \mathrm{C}_{6} \mathrm{H}_{5}\right)$. Calcd. for $\mathrm{C}_{32} \mathrm{H}_{51} \mathrm{~N}_{7} \mathrm{O}_{14} \cdot 2 \mathrm{HCl} \cdot \mathrm{H}_{2} \mathrm{O}$ : C 44.75 , $\mathrm{H}$ 6.46, N 11.42, Cl 8.26. Found: C 44.93, H 6.18, N 11.10, Cl 8.06. It should be noted that the isopropylidene group in the dihydrostreptose portion is the most stable.

Acetylation of $\mathbf{3}$ with acetic anhydride in the presence of a catalytic amount of $p$ toluenesulfonic acid at $50^{\circ} \mathrm{C}$ for 70 hours gave the hexaacetyl derivative (4); $92 \% ;[\alpha]_{\mathrm{D}}^{20}-60^{\circ}$ (c 1.4, acetone); NMR (in $\mathrm{CDCl}_{3}$ ): $\delta 1.85 \sim$ 2.2 (18H unresolved, $\mathrm{m}, \mathrm{Ac})$. Calcd. for $\mathrm{C}_{44} \mathrm{H}_{63} \mathrm{~N}_{7} \mathrm{O}_{20} \cdot 2 \mathrm{HCl}: \mathrm{C} 48.80, \mathrm{H} 6.05, \mathrm{~N} 9.05$, Cl 6.55. Found: C 48.66, H 6.05, N 8.76, Cl 6.50 .

Selective hydrolysis of 4 with $75 \%$ aqueous acetic acid at $55^{\circ} \mathrm{C}$ for 30 hours led to the compound (5), which has free primary and tertiary hydroxyl groups in the dihydrostreptose portion, $86 \% ;[\alpha]_{\mathrm{D}}^{20}-66^{\circ}$ (c 1.2 , acetone); Rf 0.5 (TLC with Avicel, pyridineethyl acetate-ether-20\% acetic acid $(2: 2: 3: 1)$, visualized by diacetyl). Calcd. for $\mathrm{C}_{41} \mathrm{H}_{59} \mathrm{~N}_{7}$ $\mathrm{O}_{20} \cdot 2 \mathrm{HCl}: \mathrm{C} 47.23, \mathrm{H} 5.90, \mathrm{~N} 9.40, \mathrm{Cl} 6.80$. Found: C 46.90, H 5.80, N 9.11, Cl 6.99. The structure (5) was confirmed by the NMR spectrum (in pyridine- $\left.d_{5}-\mathrm{D}_{2} \mathrm{O}\right): \delta 1.55(3 \mathrm{H} \mathrm{d}$, $\left.\mathrm{CCH}_{3}\right), 2.0 \sim 2.4(18 \mathrm{H} \mathrm{m}, \mathrm{Ac}), 3.37(3 \mathrm{H} \mathrm{s}$,
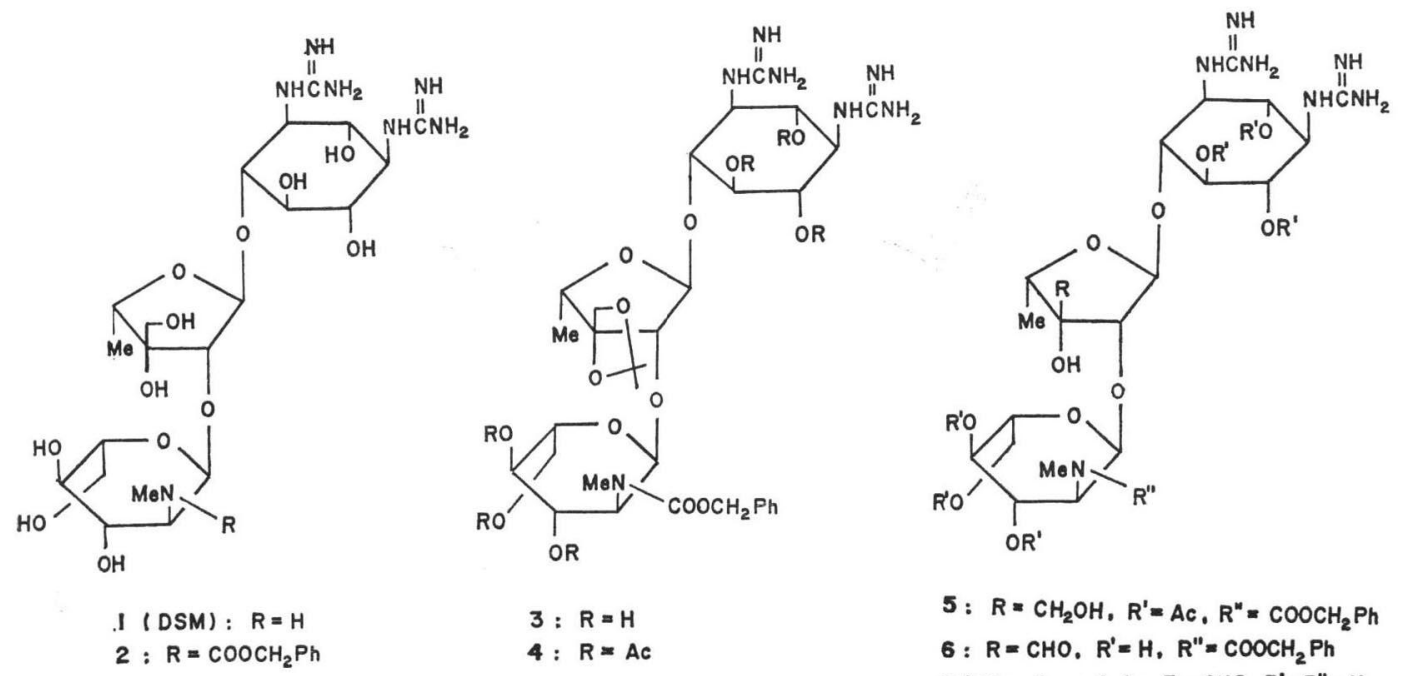

5: $R=\mathrm{CH}_{2} \mathrm{OH}, \mathrm{R}^{\prime}=\mathrm{AC}, \mathrm{R}^{\prime \prime}=\mathrm{COOCH}_{2} \mathrm{Ph}$

6 : $\mathrm{R}=\mathrm{CHO}, \mathrm{R}^{\prime}=\mathrm{H}, \mathrm{R}^{\prime \prime}=\mathrm{COOCH}_{2} \mathrm{Ph}$

7 (Streptomycin): $R=C H O, R^{\prime}=R^{\prime \prime}=H$ 
Fig. 1. NMR spectra of natural and synthetic streptomycin in $\mathrm{D}_{2} \mathrm{O}$ (DSS $0 \mathrm{ppm}$ ), $60 \mathrm{MHz}$.

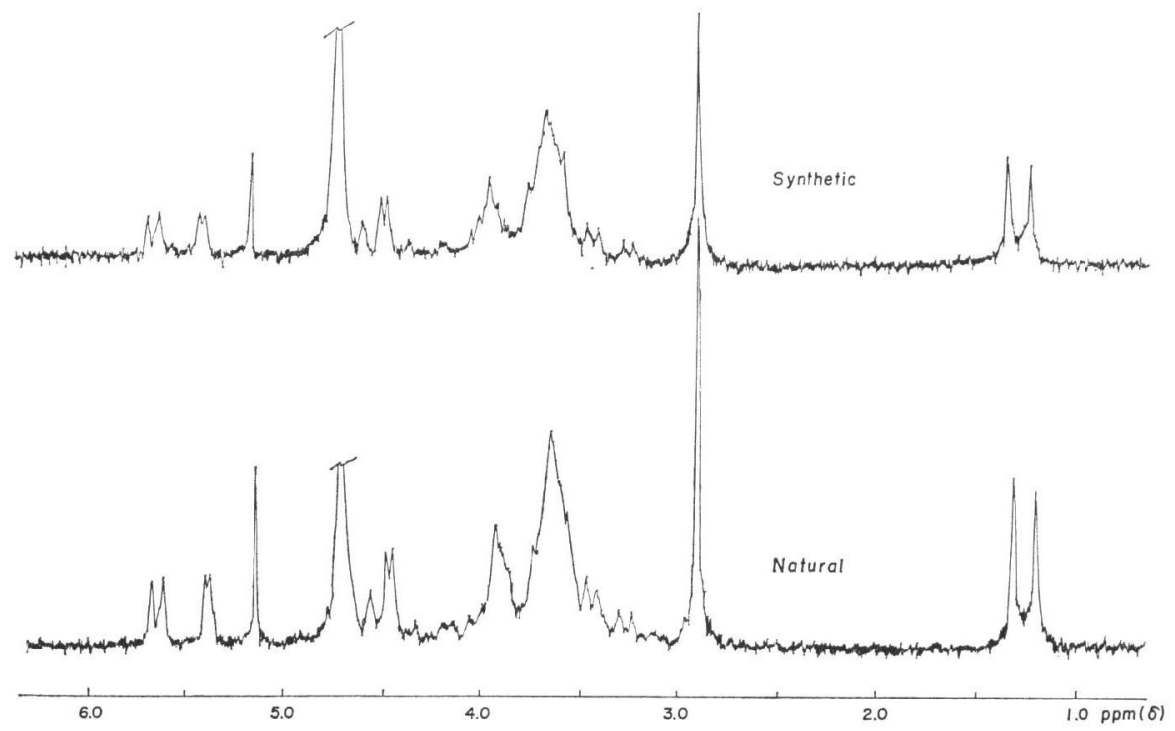

$\left.\mathrm{NCH}_{3}\right), 7.53\left(5 \mathrm{H} \mathrm{s}, \mathrm{C}_{6} \mathrm{H}_{5}\right)$.

Compound $\mathbf{5}$ was then converted into the aldehyde derivative (6) by PFitzner-Moffatt oxidation with dimethyl sulfoxide, dicyclohexylcarbodiimide, trifluoroacetic acid, and pyridine at room temperature for 1.5 hours. The desired compound from the reaction product was difficult to isolate, so the crude product was deacetylated with methanolic ammonia and chromatographed on Dowex 1 $\times 2\left(\mathrm{OH}\right.$ form) with water to afford the $2^{\prime \prime}$.
N-benzyloxycarbonylstreptomycin (6) (18\%); dihydrochloride dihydrate: $[\alpha]_{\mathrm{D}}^{28}-70^{\circ}$ (c) 1 , $\mathrm{H}_{2} \mathrm{O}$ ); NMR (in $\mathrm{D}_{2} \mathrm{O}$ ): $\delta 1.27\left(3 \mathrm{H} \mathrm{d}, \mathrm{CCH}_{3}\right.$ ), $3.10\left(3 \mathrm{H} \mathrm{s}, \mathrm{NCH}_{3}\right), 7.60\left(5 \mathrm{H} \mathrm{s}, \mathrm{C}_{6} \mathrm{H}_{5}\right)$. Calcd. for $\mathrm{C}_{29} \mathrm{H}_{45} \mathrm{~N}_{7} \mathrm{O}_{14} \cdot 2 \mathrm{HCl} \cdot 2 \mathrm{H}_{2} \mathrm{O}$ : C 42.23, $\mathrm{H}$ 6.23, $\mathrm{N}$ 11.89, $\mathrm{Cl}$ 8.60. Found: C 42.21, H 6.09, $\mathrm{N} 11.63, \mathrm{Cl}$ 8.73. Oxidation with ruthenium tetroxide was unsuccessful.

At this point, we were able to establish the identity with natural material which was prepared from natural streptomycin by benzy-

Table 1. Antibacterial spectra of natural and synthetic streptomycin

\begin{tabular}{|c|c|c|}
\hline \multirow{2}{*}{ Test organisms* } & \multicolumn{2}{|c|}{$\mathrm{MIC}(\mathrm{mcg} / \mathrm{ml})$} \\
\hline & Natural & Synthetic \\
\hline Staphylococcus aureus FDA 209P & 3.12 & 1.56 \\
\hline " $\quad " \quad$ SM ST f. & $>100$ & $>100$ \\
\hline Bacillus subtilis NRRL B. 558 & 12.5 & 6.25 \\
\hline$" \quad$ PCI 219 & 0.39 & 0.2 \\
\hline Bacillus agri & $>100$ & $>100$ \\
\hline Escherichia coli $\mathrm{K}-12$ & 1.56 & 1.56 \\
\hline$" \quad$ " ML 1629 & 100 & 100 \\
\hline " ML 1410 & 1.56 & 1.56 \\
\hline " W 677 & 1.56 & 3.12 \\
\hline " $\quad$ "JR $66 /$ W 677 & $>100$ & $>100$ \\
\hline Pseudomonas aeruginosa A3 & 25 & 25 \\
\hline Mycobacterium smegmatis ATCC $607 * *$ & 0.39 & 0.39 \\
\hline
\end{tabular}

* Agar dilution streak method (nutrient agar, $37^{\circ} \mathrm{C}, 17$ hours).

** 48 hours. 
loxycarbonylation. The specific rotation, IR and NMR spectra and chromatographic behavior of the synthetic and natural specimens were identical.

Finally, catalytic hydrogenolysis of the synthetic 6 with palladium black in aqueous solution acidified with acetic acid produced streptomycin. It should be noted that, in this case, pretreatment of the aqueous solution of 6 with a small amount of RANEY nickel improved the yield of streptomycin. By chromatography on Dowex $1 \times 2$ ( $\mathrm{Cl}$ form), we readily obtained pure streptomycin $(75 \%)$; trihydrochloride: $[\alpha]_{D}^{25}-82^{\circ}\left(c \quad 1, \mathrm{H}_{2} \mathrm{O}\right) \quad\left(\mathrm{lit}^{9)}\right.$ $\left.-86.7^{\circ},\left(c 1, \mathrm{H}_{2} \mathrm{O}\right)\right)$. The synthetic streptomycin trihydrochloride was identical with the natural specimen with respect to the IR and NMR spectra, thin-layer and paper chromatographic behavior, and antibacterial spectra. In the NMR spectra (Fig. 1), we can observe the proton singlet at $\delta 5.15$ which is due to the unusual C-3 formyl group and consisdered to be a hydrated form. ${ }^{10)}$ The antibacterial spectra (Table 1) are essentially identical, showing the same characteristic features of activity against both sensitive and resistant organisms.

\section{Acknowledgement}

The authors are grateful to Prof. Hamao UMEZAWA of the Institute of Microbial Chemistry for his important ideas and encouragement.

\section{Sumio Umezawa \\ YoshIKaZU TAKaHASHI \\ TAKAYUKI USUI \\ Tsutomu Tsuchiya}

Department of Applied Chemistry, Faculty of Engineering,

Keio University,

Hiyoshi, Yokohama, Japan

(Received October 17, 1974)

\section{References}

1) Schatz, A.; E. Bugie \& S. A. Waksman: Streptomycin, a new substance exhibiting antibiotic activity against gram-positive and gram-negative bacteria. Proc. Soc. Exptl. Biol. Med. 55: 66 69, 1944

2) Lemieux, R.U. \& M. L. Wolfrom: The chemistry of streptomycin. Advan. Carbohyd. Chem. 3: 337 384, 1948

3) McGilveray, I. J. \& K. L. Rinehart, Jr.: Anomeric linkage of streptose in streptomycin and bluensomycin. J. Amer. Chem. Soc. 87: 4003 4004, 1965

4) Neidle, S.; D. Rogers \& M. B. Hursthouse: The crystal and molecular structure of streptomycin oxime selenate. Tetrahedron Letters 1968: 4725 4728, 1968

5) Umezawa, S.; T. Tsuchiya, T. Yamasaki, H. Sano \& Y. Takahashi: Total synthesis of dihydrostreptomycin. J. Amer. Chem. Soc. 96: 920 921, 1974

6) Bartz, Q.R.; J. Controulis, H.M. Grooks, Jr. \& M. C. Rebstock: Dihydrostreptomycin. J. Amer. Chem. Soc. 68: 2163 2166, 1946

7) PeCK, R.L.; C.E. Hoffhine, Jr. \& K. Folkers: Streptomyces antibiotics. IX. Dihydrostreptomycin. J. Amer. Chem. Soc. 68: 1390 1391, 1946

8) Tatsuoka, S.; T. Kusaka, A. Miyake, M. Inoue, H. Hitomi, Y. Shiraishi, H. Iwasaki \& M. IMANishi: Antibiotics. XVI. Isolation and identification of dihydrostreptomycin produced by a new streptomyces: Streptomyces humidus nov. sp. Chem. Pharm. Bull. 5: 343 349, 1957

9) Kuehl, F.A., Jr.; R.L. Peck, C.E. Hoff hine, Jr., R.P. Graber \& K. Folkers: Streptomyces antibiotics. VIII. Isolation of streptomycin. J. Amer. Chem. Soc. 68: 1460 1462, 1946

10) Bock, K.; C. Pedersen \& H. Hedding: A ${ }^{13} \mathrm{C}-\mathrm{NMR}$ spectroscopic study of $\alpha$ - and $\beta$ streptomycin. J. Antibiotics 27: 139 140, 1974 